\title{
THE MECHANISM OF VEGF-MEDIATED ENDOTHELIAL CELLS SURVIVAL AND PROLIFERATION IN CONDITIONS OF UNFED-CULTURE
}

\author{
T. V. NIKOLAIENKO, V. V. NIKULINA, D. V. SHELEST, L. V. GARMANCHUK
}

Educational and Scientific Centre "Institute of Biology", Taras Shevchenko National University of Kyiv, Ukraine; e-mail: nikolaenkotetiana@yandex.ua

The mechanisms of VEGF-mediated effects on endothelial cells during cancer development and progression is not clear. In present study the biological effects of VEGF, VEGF-rich culture medium of peritoneal macrophages from mice with Lewis lung carcinoma were studied on MAEC cell line under conditions of unfed culture. We have shown that VEGF increased cell proliferation by the $5^{\text {th }}$ day of culturing vs control and anti$V E G F$-treated cells. This effect was associated with increased consumption of glucose and NO production by the $2^{\text {nd }}$ day while decreased - on the $5^{\text {th }}$ day of cell culturing. VEGF-mediated NO production was dependent on $\mathrm{Ca}^{2+}$ ions. Block of $\mathrm{Ca}^{2+}$-channels $\left(\mathrm{LaCl}_{3}\right)$ had more pronounced inhibitory effect vs chelator of $\mathrm{Ca}^{2+}$ ions (EDTA). It was shown that peritoneal macrophages are the main suppliers of VEGF at tumor angiogenesis, as evidenced by the data obtained on model system of endothelial cells synchronized in $G_{0} / G_{1}$ phase.

Key words: VEGF, nitric oxide, angiogenesis, eNOS, EDTA, $\mathrm{LaCl}_{3}$.

$\mathrm{T}$ he endothelial lining of blood vessels provides a barrier for the exchange of nutrients and is itself actively involved in the local control of vascular homeostasis. Physiologically, processes of proliferation and differentiation of endothelial cells are determined and regulated by a variety of biologically active molecules. The vascular endothelial growth factor (VEGF) is a potent and critical inducer of angiogenesis. Signal transduction involves binding to tyrosine kinase receptors and results in endothelial cell proliferation [1].

VEGF affects the basic functional characteristics of endothelial cells, such as adhesion, proliferation, migration, intracellular mitogenic signal transmission, intercellular contacts, vascularization and neovascularization [2]. All these processes are not dependent on the presence of growth factors in the environment, but also on the trophic substrates. Glucose is an essential metabolic substrate of all mammalian cells for energy demand.

Glucose is taken up into cells by energy-independent transportation down its concentration gradient, which is mediated by glucose transporter proteins. Transport of glucose across the plasma membrane of mammalian cells is the first rate-limiting step for glucose metabolism and is mediated by facilitative glucose transporter (GLUT) proteins [3].
GLUT-1 is glucose transporter which is expressed in endothelial cells.

VEGF plays a key role in angiogenesis and there are only limited studies of the effects of VEGF on endothelial cell amino acid and glucose transport. VEGF enhances microvascular permeability and modulates $\mathrm{Ca}^{2+}$ signaling in endothelial cells and causes an approximately threefold increase in 2-deoxyglucose uptake and a fivefold increase in GLUT1 transcript [4].

Glucose transporter is also a proliferation-related gene and its expression is associated with the activation of signal transduction mechanisms, its expression should also be induced when a growth factor binds to its receptor. VEGF exerts its mitogenic effects in various types of tumor cells, in part, by inducing the expression of genes whose products are required for endothelial cells proliferation and cancer progression. Given evidence that VEGF may act as a survival factor in tumor, the ability of VEGF to regulate endothelial cell glucose transport in conjunction with angiogenesis may serve to ensure adequate substrate delivery and blood flow during tumor progression [5].

Angiogenesis is initiated by vasodilatation, a NO-mediated process. Nitric oxide (NO) is a diffusible gas that is produced from L-arginine in 
the large number of tissues by the NO synthase (NOS) family of enzymes. There are three isoforms of NOS: nNOS (type I), iNOS (type II), and eNOS (type III). There is mounting evidence demonstrating the interaction between NO and VEGF. It has been convincingly demonstrated that NO may be involved in endothelial cell proliferation, migration, protease release, increased vascular permeability and effects important for initiation of angiogenesis [6].

Both inflammation and angiogenesis are exacerbated by increased production of chemokines/ cytokines, growth factors, proteolytic enzymes, lipid mediators and prostaglandins. Initiation and progression of cancer are also closely linked to angiogenesis. Infiltration of macrophages is a dramatic and common feature of inflammation, angiogenesis and cancer, and has been recently highlighted in an attempt to develop novel strategies for treating cancer [7]. By release of secretory products the activated macrophages have the capability to influence each phase of the angiogenic process, such as alterations of the local extracellular matrix, induction of endothelial cells to migrate or proliferate, and inhibition of vascular growth with formation of differentiated capillaries [8].

The aim of the present work was to study biological effects of VEGF on endothelial cells in the conditions of unfed culture.

\section{Materials and Methods}

All experiments were performed in compliance with the "Guide for the Care and Use of Experimental Animals" approved by the Committee for control of maintenance and use of experimental animals of ESC Institute of Biology at Taras Shevchenko National University of Kyiv.

Model systems. Mouse aortic endothelial cell line (MAEC) isolated from mouse aorta and spontaneously immortalized in culture was used $[9,10]$. MAEC preserves the main biological properties of normal endotheliocytes, including the ability to differentiation and formation of procapillary structures in vitro. MAEC was incubated in DMEM medium (Sigma, USA) supplemented with 10\% FBS (Sigma, USA), $2 \mathrm{mM}$ L-glutamine and $40 \mathrm{mg} / \mathrm{ml}$ gentamicin. Cell lines were cultured under the standard conditions at $37{ }^{\circ} \mathrm{C}$ in humidified atmosphere with $5 \%$ $\mathrm{CO}_{2}$.

Mononuclear phagocyte fraction of peritoneal exudate of mice with Lewis lung carcinoma at various stages of tumor growth was obtained by stand- ard procedure of Pietrangeli [11]. Macrophages were incubated under standard conditions at $37^{\circ} \mathrm{C}, 100 \%$ humidity and $5 \% \mathrm{CO}_{2}$ for $4 \mathrm{~h}$ and then their cultural medium was added to MAEC culture.

Test agents. After adaptation of cells to culture medium test-agents were added: VEGF (vascular endothelial growth factor), obtained previously [12], anti-VEGF (monoclonal antibody specific for VEGF), condition medium from peritoneal macrophages from mice with Lewis lung carcinoma at various stages of tumor growth, chelator of $\mathrm{Ca}^{2+}$ (EDTA) and blocker of $\mathrm{Ca}^{2+}$-channels $\left(\mathrm{LaCl}_{3}\right)$.

Proliferative assay. The number of living cells was determined in wells using MTT-colorymetric test [13] and cell counts were performed using a trypan blue dye after incubation with agents. The biochemical essence of this method is based on the fact that mitochondrial dehydrogenases of living cells are capable of cleaving tetrazolium rings with formation of insoluble purple crystals (formazan). MTT $(20 \mu \mathrm{l})$ was added to the culture medium $4 \mathrm{~h}$ before the termination of the cells incubation in order to achieve the final concentration of $0.6 \mathrm{mM}$. Formazan crystals formed after the incubation with MTT were dissolved in $100 \mu$ l of dimethylsulfoxide. The plate was analyzed on the spectrophotometer at $540 \mathrm{~nm}$.

Flow cytometry. Apoptotic level and distribution of cells in phases of cell cycle were assessed by cytofluorimetry [14]. Cytofluorimetry was carried out on the instrument FACS Calibur (Becton Dickinson, United States). Special mathematical program Mod Fit LT 2.0 (BDIS, United States) for Macintosh computers was used for acquisition and data analysis. Narrowband filter $585 / 42 \mathrm{~nm}$ was used in order to measure the fluorescence of PI.

Determination of glucose by glucose-oxidase method. The level of glucose in the incubation medium of endothelial cells was determined using a standard set based on glucose-oxidase reaction which we modified for culture medium of cells. Initial cell concentration was about $1 \times 10^{5}$ cells $/ \mathrm{ml}$ in the sample volume of $200 \mu 1$. Determination was performed according to the protocol of the manufacturer "Felicit-Diagnostics" (Ukraine) [15].

Determination of the nitrite anion concentration. The content of NO was determined by colorimetric assay using the Griess reagent [16]. Sodium nitrite solution $0.2-10 \mu \mathrm{M}$ was used for calibration.

Determination of the level of production VEGF. ELISA was used to determine the level of VEGF in 
culture medium [17]. The procedure for determining the concentration of VEGF was carried out in 96well plates with immobilized antibodies. The level of VEGF was determined by the calibrating curve, which was built as the absorbance dependence on the concentration of VEGF.

Statistical analysis. Experimental data were analysed using descriptive methods, by Student's $t$ criterion and by the method of nonlinear regression.

\section{Results and Discussion}

Angiogenesis is known as a multi-step process which consists of remodeling of extracellular matrix, proliferation and migration of endothelial cells, changes in metabolism of endothelial cells, tube formation and blood vessels stabilization [18]. It is regulated by a well-orchestrated balance between pro- and anti-angiogenic factors. Since VEGF plays a key role in angiogenesis, we tested its effect on endothelial cells (MAEC). At the first step of the study the cultivation of endothelial cells with exogenous VEGF and anti-VEGF was conducted within 5 days. The cultivation of endothelial cells was conducted during five days for modeling 2 systems of growth exponential (cells proliferate actively) and stationary (most of the cell is in $G_{0} / G_{1}$ phase) ones. Their effects on cell survival and changes in the metabolism of glucose as the main energy substrate were determined. The cultivation is conducted under conditions of unfed culture and determination of glucose and counting of live/dead cells using trypan blue dye was carried out at every stage.

VEGF stimulates cell proliferation and increases the number of cells 1.6 and 2 times on the fifth day compared with control and anti-VEGF, respectively (Fig. 1). In addition, the number of dead cells during the period of the experiment is the lowest under the influence VEGF of about $4.0 \pm 0.2 \%$ $(P<0.05)$ and $6.0 \pm 0.4 \%(P<0.05)$ compared with the control and anti-VEGF, respectively. Thus, VEGF showed a significant proliferative, angiogenic effect on endothelial cells and is a factor of cell survival.

The level of glucose consumption by cells changes depending on the duration of cultivation and the influence of agents. VEGF increased glucose consumption by cells 1.5 times and 1.4 times compared with the control and anti-VEGF, respectively, (Fig. 2) on the first day of incubation. However, on other days the opposite situation was observed, the number of cells was increased significantly, while

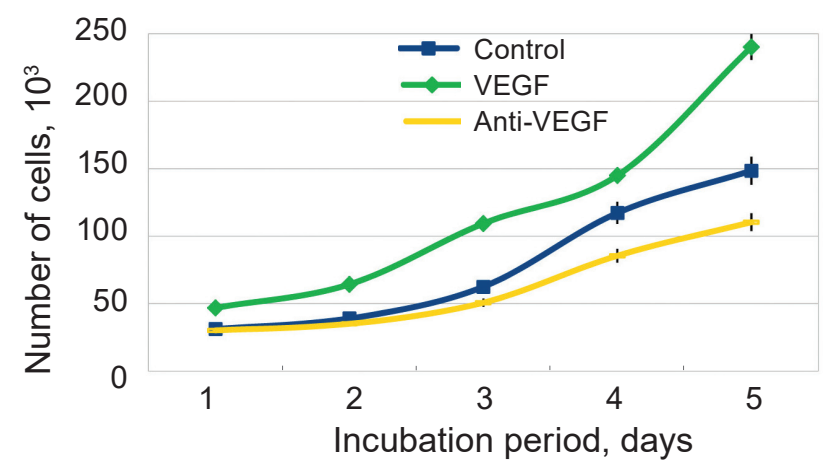

Fig. 1. The influence of VEGF and anti-VEGF on proliferation of endothelial cells

glucose consumption by cells was reduced. This effect may be explained by stimulation of glutamine transport from culture medium by VEGF and its involvement in metabolic pathways of cells. The transport of amino acids (including L-glutamine) is a $\mathrm{Na}^{+}$-dependent process, so activation of L-glutamine transport via the $\mathrm{Na}^{+}$-dependent system was dependent on de novo protein and RNA synthesis, and L-glutamine supplementation protected endothelial cells from oxidant injury which promotes cell survival [19]. In one of the few studies focused on endothelial cell metabolism measurements of the maximum catalytic activities of the major metabolic pathways demonstrated that, in addition to glucose and fatty acids, glutamine represents an important fuel for these cells. In particular, the activity of glutaminase is about 20-fold higher in endothelial cells than in lymphocytes (known to exhibit high rates of glutaminolysis). These data confirm that the endothelial cells like tumor cells can produce biosynthetic intermediates via the TCA cycle independent of coupling by OXPHOS machinery [20].

The angiogenic and inflammatory effects of VEGF can be mediated by NO, which is produced by VEGF-activated eNOS in endothelial cell. It has been reported that VEGFR-2 plays a major role in angiogenesis, and its autophosphorylation leads to eNOS activation [21]. NO-production during 5 days of cultivation of endothelial cells under the conditions of unfed culture was determined and its specific effects were identified. As it can be seen in Fig. 3 VEGF stimulates NO-production 2.3 times on the first day and 3.5 times on the second day compared with the control. Activating effect of anti-VEGF relative to the production of nitric oxide on the $4^{\text {th }}-5^{\text {th }}$ day of incubation is shown. More prolonged action of antiVEGF can be explained by depletion of incubation 


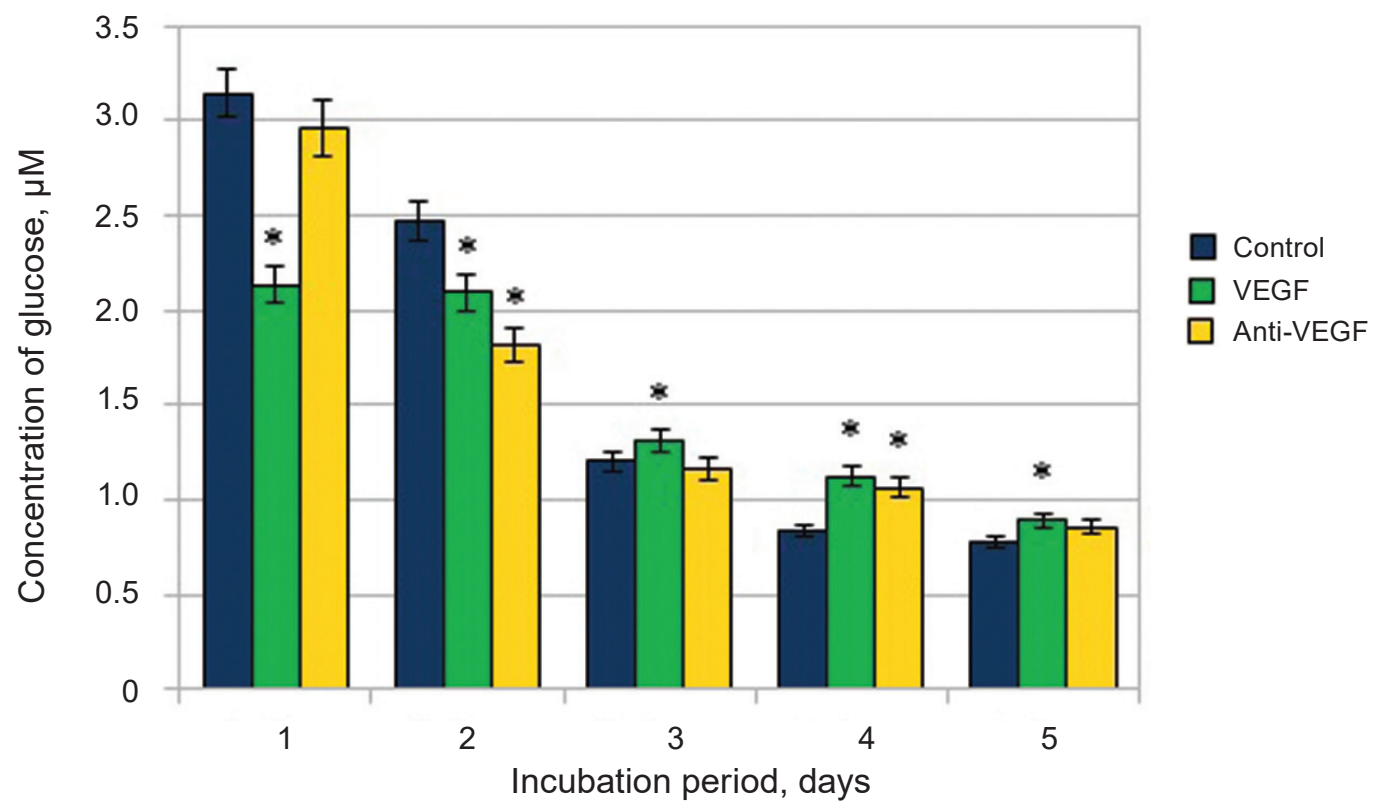

Fig. 2. The influence of VEGF and anti-VEGF on consumption of glucose by endothelial cells; $M \pm m, n=5$, $* P<0.05$ relative to control

medium on trophic substrates and humoral factors which are contained in the serum.

Nitric oxide demonstrated multidirectional action, because the increase of its concentration under the influence of VEGF significantly stimulated the proliferation of endothelial cells, while its increase under the influence of anti-VEGF leads to increasing the number of apoptotic cells. Nitric oxide showed proapoptotic effect in relation to the endothelial cells under the influence of anti-VEGF, as evidenced by the increasing number of apoptotic cells compared with the control and under the influence of VEGF. So, the effect of nitric oxide on endothelial cells depends on its concentration in the incubation medium and on microenvironment conditions.

The activity of eNOS by blocking $\mathrm{Ca}^{2+}$-channels was determined to confirm the data on eNOS involvement in production of nitric oxide and specificity of its activation under the influence of VEGF in our experimental conditions. The constitutive eNOS

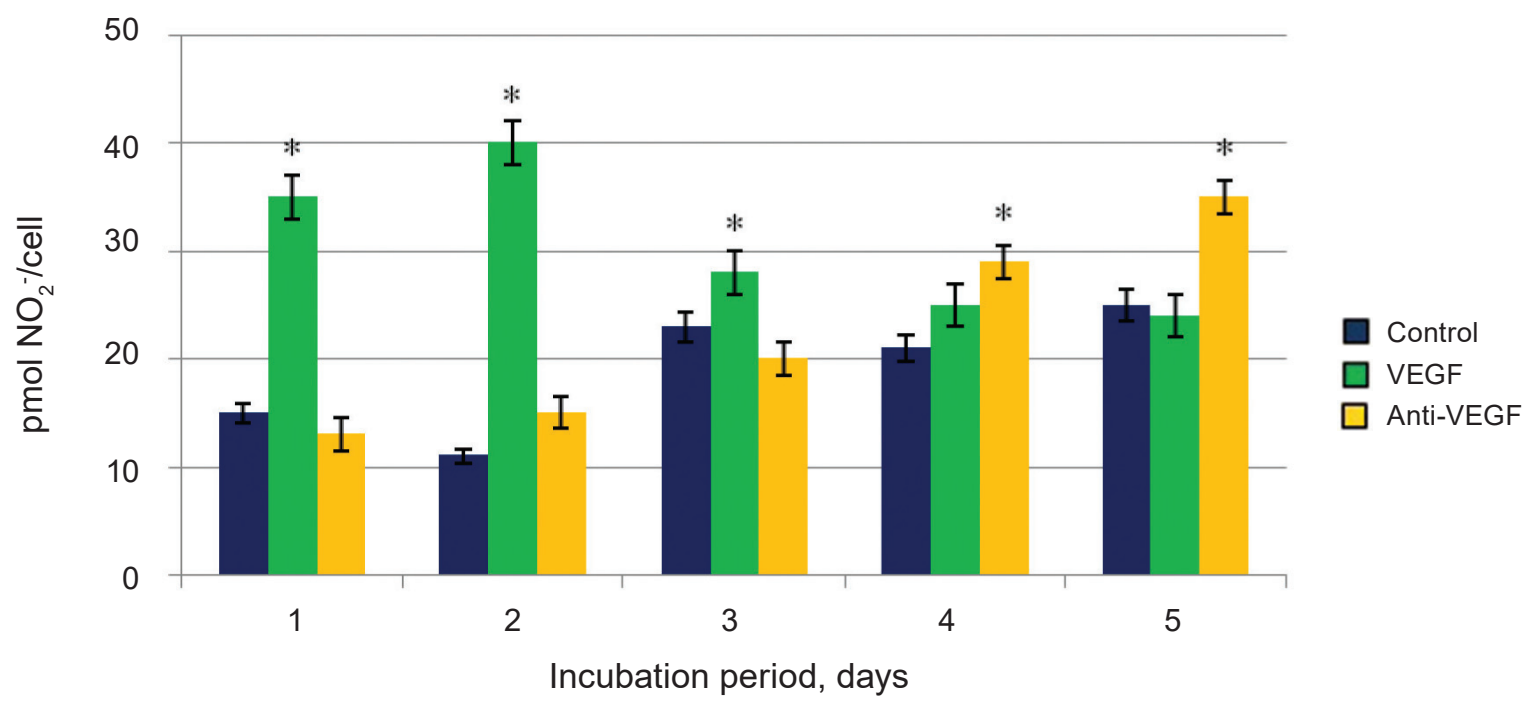

Fig. 3. The influence of VEGF and anti-VEGF on NO-production by endothelial cells. Calculation is conducted according to the culture medium volume and the number of cells; $M \pm m, n=5, * P<0.05$ relative to control 
can be activated by receptor-dependent and -independent agonists as a consequence of an increase in the concentration of free $\mathrm{Ca}^{2+}$ and the association of $\mathrm{a} \mathrm{Ca}^{2+} /$ calmodulin $(\mathrm{CaM})$ complex with the enzyme [22]. For this purpose EDTA $(100 \mu \mathrm{M})$ and $\mathrm{LaCl}_{3}$ $(1 \mu \mathrm{M})$ were used that bind and block the entry of calcium into cells. The most pronounced effect of VEGF and anti-VEGF were found on the second and fifth days of cultivation, so they were selected for the experiment. Although a significant stimulation of production of nitric oxide under influence of VEGF on the second and the fifth days under influence of anti-VEGF is shown, EDTA and $\mathrm{LaCl}_{3}$ significantly reduce the level of NO (Fig. 4).

In addition, both agents have different effect on production of nitric oxide by endothelial cells. $\mathrm{LaCl}_{3}$ has more pronounced inhibitory effect, because it selectively binds with $\mathrm{Ca}^{2+}$-channels.

It is known that macrophages are supposed to play a key role in inflammatory and tumor angiogenesis. The recruitment and infiltration of tumor-associated macrophages in the tumor microenvironment activates them to support the malignant progression of cancer cells [7]. Therefore the next stage of our study was aimed to identify the angiogenic properties of the medium of cultivation macrophages derived from animals with Lewis lung carcinoma in various stages of tumor growth.

The peritoneal macrophages was obtained from mice with Lewis lung carcinoma and cultured under

A

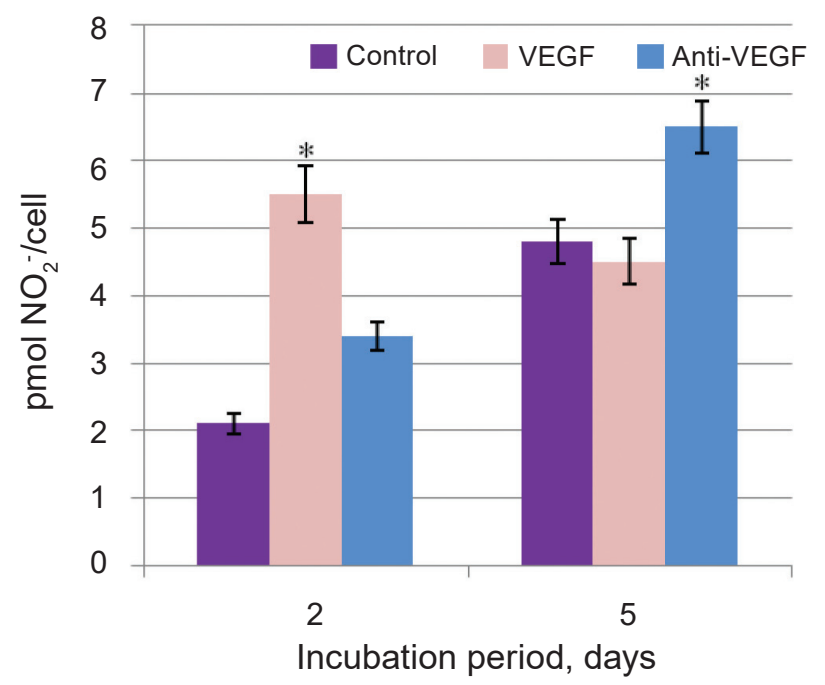

standard conditions. Culture medium was collected and added to the culture of endothelial cells, the level of VEGF was determined.

The increase of VEGF production on the $7^{\text {th }}$ day about 2 times, $19^{\text {th }}$ day $-4.5,25^{\text {th }}$ day -4.7 was observed as compared to intact group (Fig. 5). Since the $19^{\text {th }}$ and $25^{\text {th }}$ days are characterized by intensive development of tumors and metastasis, the hypoxic areas are formed in this period of time. This process induces macrophages to increase production of VEGF for improving the access of oxygen and nutrients in these areas.

The $15.0 \pm 0.4 \%(P<0.05)$ increase of glucose consumption by endothelial cells is shown, compared to the intact group under the influence of incubation medium of macrophages, on the $19^{\text {th }}$ and $25^{\text {th }}$ days. This indicates an intensification of metabolic processes in cells associated with the transition to the synthetic phase of the cell cycle.

Endothelial cells of the control group passed to $\mathrm{S}+\mathrm{G}_{2} / \mathrm{M}$ by $5.32 \pm 0.34 \%(P<0.05)$, while the number of cells stimulated by incubation medium of peritoneal macrophages on the $19^{\text {th }}$ and $25^{\text {th }}$ days which passed to $\mathrm{S}+\mathrm{G}_{2} / \mathrm{M}$ increased by $52.82 \pm 3.25 \%$ and $49.72 \pm 2.82 \%(P<0.05)$, respectively (Fig. 6). The highest level of cells in $\mathrm{S}+\mathrm{G}_{2} / \mathrm{M}$ observed on the $7^{\text {th }}$ day of tumor growth and is $36.32 \pm 1.25 \%$. Thus, a significant stimulation of cells switching from $\mathrm{G}_{0} /$ $\mathrm{G}_{1}$ to $\mathrm{S}+\mathrm{G}_{2} / \mathrm{M}$ under the influence of incubation medium of peritoneal macrophages from animals with

Fig. 4. The influence of EDTA (A) and $\mathrm{LaCl}_{3}(B)$ on NO-production by endothelial cells. Calculation is conducted according to the culture medium volume and number of cells; $M \pm m, n=5, * P<0.05$ relative to control 


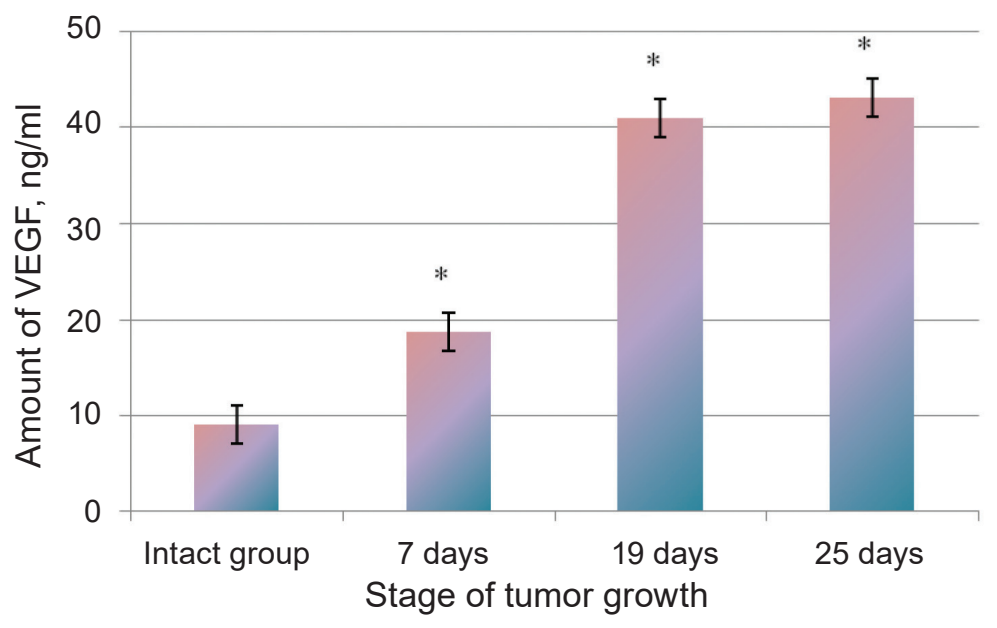

Fig. 5. The level of VEGF production by peritoneal macrophages of mice at the different stages of tumor growth of Lewis lung carcinoma; $M \pm m, n=5, * P<0.05$ relative to intact group

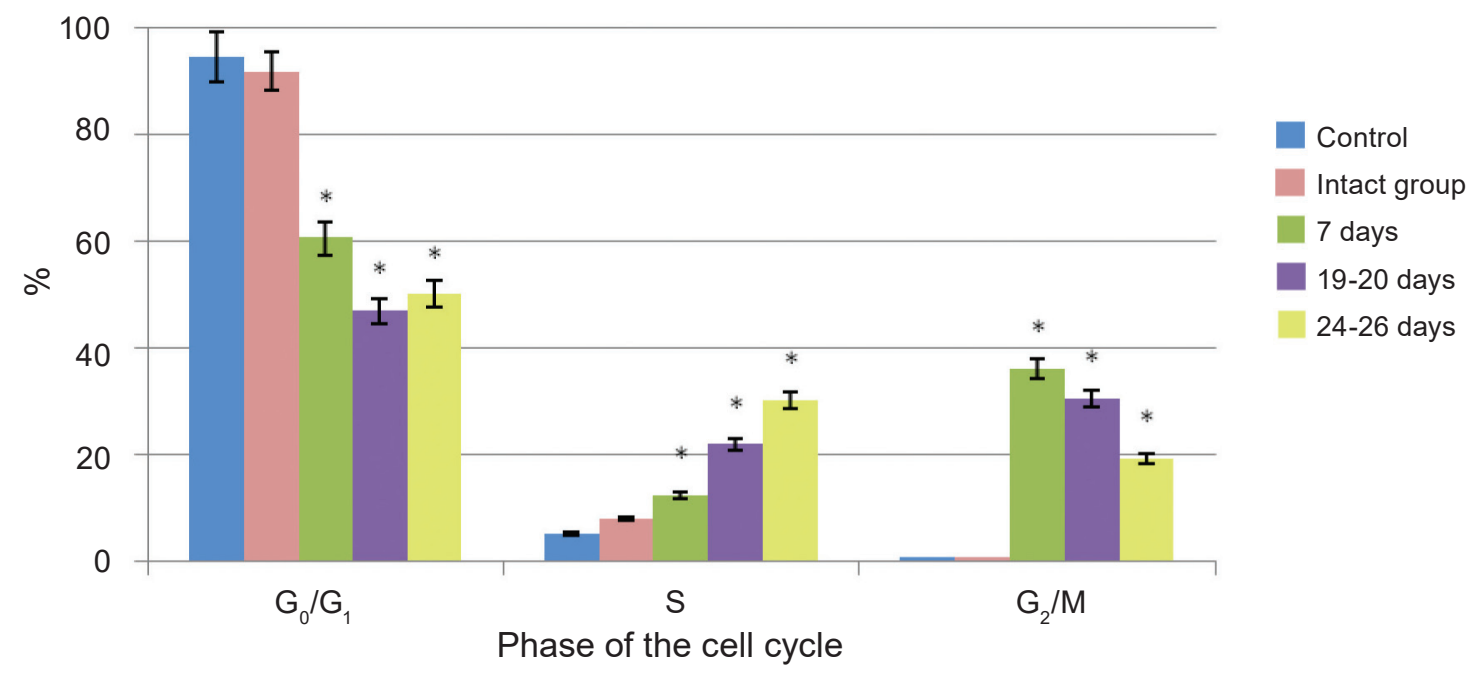

Fig. 6. The distribution of phases of the cell cycle by MAEC after incubation with macrophages of mice at different stages of growth of Lewis lung carcinoma; $M \pm m, n=5, * P<0.05$ relative to intact group

Lewis lung carcinoma may be traced, that indicates the involvement of macrophages in tumor angiogenesis.

In conclusion, the study detected a relationship of glucose uptake and production of nitric oxide under the influence of VEGF and anti-VEGF by endothelial cells in conditions of unfed culture. Thus activation of glycolysis is characteristic not only of tumor cells but also of endothelial ones. Nitric oxide demonstrated multidirectional action on endothelial cells that depends on its concentration in the incubation medium and microenvironment conditions. It is shown that not only tumor cells are suppliers of VEGF at tumor angiogenesis but also the immunocompetent cells, including macrophages. This was demonstrated on a model system of endothelial cells synchronized in $\mathrm{G}_{0} / \mathrm{G}_{1}$ phase with the medium of cultivation macrophages derived from animals with Lewis lung carcinoma at various stages of tumor growth. 


\section{МЕХАНІЗМИ VEGF- ОПОСЕРЕДКОВАНОГО ВИЖИВАННЯ ТА ПРОЛІФЕРАЦЇ̈ ЕНДОТЕЛІАЛЬНИХ КЛІТИН В УМОВАХ ДОВГОТРИВАЛОГО КУЛЬТИВУВАННЯ БЕЗ ЗАМІНИ СЕРЕДОВИЩА}

T. В. Ніколаєнко, В. В. Нікуліна, Д. В. Шелест, Л. В. Гарманчук

ННЦ «Інститут біології», Київський національний університет імені Тараса Шевченка, Україна; e-mail: nikolaenkotetiana@yandex.ua

Механізми VEGF-опосередкованих ефектів на ендотеліальні клітини під час розвитку та прогресії раку досі залишаються повністю нез'ясованими. Досліджено біологічні ефекти VEGF, VEGF-збагаченого середовища культивування перитонеальних макрофагів мишей з карциномою легенів Льюїс на лінію ендотеліальних клітин МАЕС за довготривалого культивування без заміни середовища інкубації. Показано, що VEGF підвищував проліферацію клітин на 5-й день культивування в порівнянні 3 контролем та клітинами, що оброблялися анти-VEGF. Цей ефект був пов'язаний з підвищенням споживання глюкози і продукції NO на 2-й день та зниженням - на 5-й день культивування клітин. VEGF-опосередкована продукція NO залежала від $\mathrm{Ca}^{2+}$. Блокатор $\mathrm{Ca}^{2+}$-каналів $\left(\mathrm{LaCl}_{3}\right)$ виявив вираженіший інгібувальний ефект в порівнянні 3 хелатором $\mathrm{Ca}^{2+}$ (ЕДТА). Показано, що перитонеальні макрофаги є одними з головних постачальників VEGF в умовах ангіогенезу пухлини, про що свідчать одержані дані на модельній системі ендотеліоцитів, синхронізованих у $\mathrm{G}_{0} / \mathrm{G}_{1}$ фазі.

К люч чв і слова: VEGF, оксид азоту, ангіогенез, eNOS, EDTA, $\mathrm{LaCl}_{3}$.

\author{
МЕХАНИЗМЫ VEGF- \\ ОПОСРЕДОВАННОГО \\ ВЫЖИВАНИЯ И ПРОЛИФЕРАЦИИ \\ ЭНДОТЕЛИАЛЬНЫХ КЛЕТОК \\ В УСЛОВИЯХ ДЛИТЕЛЬНОГО \\ КУЛЬТИВИРОВАНИЯ БЕЗ ЗАМЕНЫ \\ СРЕДЫ
}

\author{
T. В. Николаенко, В. В. Никулина, \\ Д. В. Шелест, Л. В. Гарманчук
УНЦ «Институт биологии», Киевский национальный университет имени Тараса Шевченко, Украина;
e-mail: nikolaenkotetiana@yandex.ua

Механизмы VEGF-опосредованных эффектов на эндотелиальные клетки при развитии и прогрессии рака до сих пор остаются полностью невыясненными. Исследованы биологические эффекты VEGF, VEGF-обогащенной среды культивирования перитонеальных макрофагов мышей с карциномой легких Льюис на линию эндотелиальных клеток МАЕС в условиях длительного культивирования без замены среды инкубации. Показано, что VEGF повышал пролиферацию клеток на 5-й день культивирования по сравнению с контролем и клетками, которые обрабатывались анти-VEGF. Этот эффект был связан с повышением потребления глюкозы и продукции NO на 2-й день и снижением - на 5-й день культивирования клеток. VEGF-опосредованная продукция $\mathrm{NO}$ зависела от $\mathrm{Ca}^{2+}$. Блокатор $\mathrm{Ca}^{2+}$ каналов $\left(\mathrm{LaCl}_{3}\right)$ проявил более выраженный ингибирующий эффект по сравнению с хелатором $\mathrm{Ca}^{2+}$ (ЭДТА). Показано, что перитонеальные макрофаги являются одними из главных поставщиков VEGF в условиях ангиогенеза опухоли, о чем свидетельствуют полученные данные на модельной системе эндотелиоцитов синхронизированных в $\mathrm{G}_{0} / \mathrm{G}_{1}$ фазе.

Ключе вы е слов в: VEGF, оксид азота, ангиогенез, eNOS, EDTA, $\mathrm{LaCl}_{3}$. 


\section{References}

1. Arutyunyan I, Fatkhudinov T, Kananykhina E, Usman N, Elchaninov A, Makarov A, Bolshakova G, Goldshtein D, Sukhikh G. Role of VEGF-A in angiogenesis promoted by umbilical cord-derived mesenchymal stromal/stem cells: in vitro study. Stem Cell Res Ther. 2016; 7: 46.

2. Szabo E, Schneider H, Seystahl K, Rushing EJ, Herting F, Weidner KM, Weller M. Autocrine VEGFR1 and VEGFR2 signaling promotes survival in human glioblastoma models in vitro and in vivo. Neuro Oncol. 2016. pii: now043.

3. Yeh WL, Lin CJ, Fu WM. Enhancement of glucose transporter expression of brain endothelial cells by vascular endothelial growth factor derived from glioma exposed to hypoxia. Mol Pharmacol. 2008; 73(1): 170-177.

4. Mann GE, Yudilevich DL, Sobrevia L. Regulation of amino acid and glucose transporters in endothelial and smooth muscle cells. Physiol Rev. 2003; 83(1): 183-252.

5. Ezhilarasan R, Mohanam I, Govindarajan K, Mohanam S. Glioma cells suppress hypoxiainduced endothelial cell apoptosis and promote the angiogenic process. Int J Oncol. 2007; 30(3): 701-707.

6. Babaei S, Stewart DJ. Overexpression of endothelial NO synthase induces angiogenesis in a co-culture model. Cardiovasc Res. 2002; 55(1): 190-200.

7. Ono M. Molecular links between tumor angiogenesis and inflammation: inflammatory stimuli of macrophages and cancer cells as targets for therapeutic strategy. Cancer Sci. 2008; 99(8): 1501-1506.

8. Khan MA, Assiri AM, Broering DC. Complement and macrophage crosstalk during process of angiogenesis in tumor progression. J Biomed Sci. 2015; 22: 58.

9. Rodrigues SF, Granger DN. Blood cells and endothelial barrier function. Tissue Barriers. 2015; 3(1-2): e978720.

10. Bastaki M, Nelli EE, Dell'Era P, Rusnati M, Molinari-Tosatti MP, Parolini S, Auerbach R, Ruco LP, Possati L, Presta M. Basic fibroblast growth factor-induced angiogenic phenotype in mouse endothelium. A study of aortic and microvascular endothelial cell lines. Arterioscler Thromb Vasc Biol. 1997; 17(3): 454-464.

11. Pietrangeli CE, Skamene E, Edelson PJ, Kongshavn PA. Measurement of 5'-nucleotidase in mouse peritoneal macrophages in listeriosis. Infect Immun. 1981; 32(3): 1206-1210.

12. Garmanchouk LV, Pyaskovskaya ON, Solyanik GI. Influence of pro-angiogenic cytokines on proliferative activity and survival of endothelial cells. Biopolym Cell. 2010; 26(3): 187-193.

13. Mosmann T. Rapid colorimetric assay for cellular growth and survival: application to proliferation and cytotoxicity assays. J Immunol Methods. 1983; 65(1-2): 55-63.

14. Nicoletti I, Migliorati G, Pagliacci MC, Grignani F, Riccardi C. A rapid and simple method for measuring thymocyte apoptosis by propidium iodide staining and flow cytometry. J Immunol Methods. 1991; 139(2): 271-279.

15. Nikolaienko T, Petruk N, Shelest D, Garmanchuk L. Influence of VEGF, EGF and their antagonists on proliferative activity and glucose consumption by endothelial cells. Bull. T. Shevchenko Nat. Univ. Kyiv. 2015; 1(69): 36-38.

16. Green LC, Wagner DA, Glogowski J, Skipper PL, Wishnok JS, Tannenbaum SR. Analysis of nitrate, nitrite, and $[15 \mathrm{~N}]$ nitrate in biological fluids. Anal Biochem. 1982 126(1): 131-138.

17. Conn G, Soderman DD, Schaeffer MT, Wile M, Hatcher VB, Thomas KA. Purification of a glycoprotein vascular endothelial cell mitogen from a rat glioma-derived cell line. Proc Natl Acad Sci USA. 1990; 87(4): 1323-1327.

18. Carmeliet P, Jain RK. Principles and mechanisms of vessel normalization for cancer and other angiogenic diseases. Nat Rev Drug Discov. 2011; 10(6): 417-427.

19. Dvorak HF. Tumor Stroma, Tumor Blood Vessels, and Antiangiogenesis Therapy. Cancer J. 2015; 21(4):237-243.

20. Polet F, Feron O. Endothelial cell metabolism and tumour angiogenesis: glucose and glutamine as essential fuels and lactate as the driving force. J Intern Med. 2013;273(2): 156-165.

21. Kimura H, Ogura T, Kurashima Y, Weisz A, Esumi H. Effects of nitric oxide donors on vascular endothelial growth factor gene induction. Biochem Biophys Res Commun. 2002; 296(4): 976-982.

22. Fleming I, Fisslthaler B, Dimmeler S, Kemp BE, Busse R. Phosphorylation of Thr(495) regulates $\mathrm{Ca}(2+) /$ calmodulin-dependent endothelial nitric oxide synthase activity. Circ Res. 2001; 88(11): E68-E75. 